\section{カッシーニの三角点 計量計測の原点を探して (1)}

計量史学会理事・スミソニアン協会特別研究員 松本栄寿(正員)

ルーブル美術館，ラファイエット・デパート，エッフェ ル塔，だれしもが思い浮かぶパリの名所である。それにも ましてパリが, 近代計量計測の原点メートル法発足の地で あることを忘れないでいただきたい（図 1)。

2003 年 9 月のこと筆者はパリの街角で一冊の本を買っ た。『命をかけた科学』[La science au péril de sa vie] ${ }^{\text {ia }}$, メートル法の測量物語である。その表紙裏に奇妙な写真を 見つけた。モンマルトルの三角点, 1736 年カッシーニに よって建てられたとある。時代はフランス革命の前であ る。カッシーニとは，1997 年に NASA が打ち上げた土星 探検の人工衛星の名でもある。ぜひ見たい，写真を撮りた い。だが，それからが難関であった。

ジャン・ドミニコ・カッシーニ（1625～1712）はイタリ ア生まれの天文学者。1669 年にフランスに招かれ新設の フランス天文台の所長となり，のちフランスに帰化した人 物である。カッシーニは一族四代にわたってフランス天文 台の館長を務めた。この三角点の設立は息子のジャック・ カシーニ (1677〜 1756) の時代であろう。フランスがペル ーやスェーデンで大規模な測量を実施したころである。

実物はどこにあるのだろうか。国際計量史学会，オッケ 会長をリールに訪ねたおりに尋ねた。 オッケ氏はじっと本の写真を眺めて, 「さてどこだろうな，遠くに見えるの はサクレ・クール寺院かもしれない な」とつぶやいた。矢も盾もたまら ず，翌日の予定をキャンセルしてモン マルトルのサクレ・クール寺院のまわ りを探し歩いた。ここには19世紀に 芸術家達が集った。ルノワールも立ち 寄ったレストランや「ギャレットの風 車小屋」も残る地である。だが，半日 歩き回っても，近くのレストランで聞 いても分からない。夕闇せまるモンマ ルトルを後に，とぼとぼとドゴール空 港から日本へと引き上げた。

帰国後もその思いは消えない。幸
い, 2004 年 7 月にロンドンでフレミング百周年記念大会 が開催され，同時に郊外のブレッチィパークでIEEEの 「エレクトロニクスの歴史」学会も開催された。その帰り パリに立ち寄り再び挑戦する機会にめぐまれた。今回は事 前に, CNAM（フランス工芸技術博物館）の学芸員メル シェ氏に問い合わせて情報をもらった。「三角点は個人の 敷地なので通常は見られない。事前に持ち主と管理人の許 可をもらう必要があるので, 私が話しておこう」との好意 ある助言である。

今度こそはと張り切って出かけたが, 土壇場になってメ ルシェ氏はバカンスで留守, 東京とロンドンから, パリに 着いてからも管理組合と地主へ再三の手紙を出して,さら に電話でだめ押し，ようやく許可がとれた。とうとう一年 かかってたどり着いた。電気錠のある門の前でボタンを押 して待つこと 5 分, 現れたメイドさんはポルトガルの女性 とのこと, 日本から 12 時間の旅をした甲斐はあった。

実はこの敷地の片隅にたたずむ三角点・北標識（Mire du Nord）と, 市の南側天文台にある南標識（Mire du Sud）をむすぶパリ市内を通る子午線は，フランスが世界 の本初子午線として, 経度の基準を主張した基点である。 1884 年にイギリスのグリニッジ天文台を通る本初子午線 が世界に認められても，1911年まではその主張を変えず 対抗していた原点である。三角点は歴史の奥深く眠ってい るようであった（図 2)。

注：Arkan SIMAN : “La Science au péril de sa vie”, VUIBERT/ ADAPT (2002)

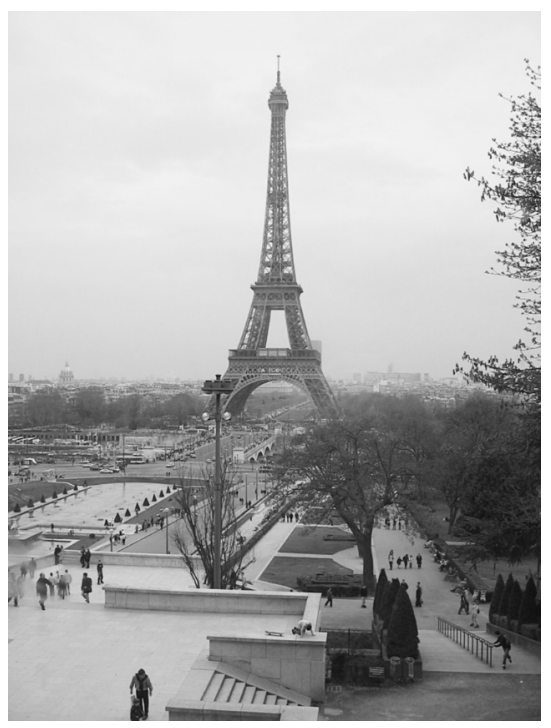

図 1 パリの夢・エッフェル塔

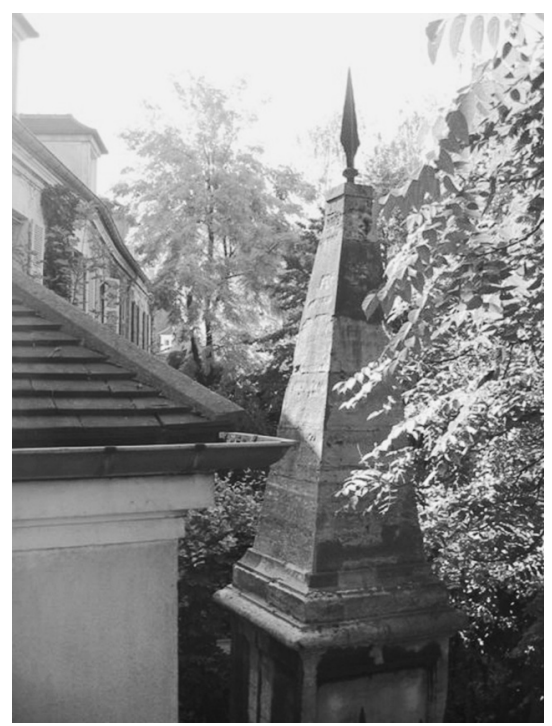

図 2 カッシーニの三角点 